\title{
Comparing smoking and smoking cessation process in the Republic of Karelia, Russia and North Karelia, Finland
}

\author{
Tiina Laatikainen, Erkki Vartiainen, Pekka Puska
}

\begin{abstract}
Study objective-The aims of this study were to assess and validate self reported smoking prevalence and to assess smoking cessation related process variables in the Republic of Karelia, Russia and in North Karelia, Finland.

Design-Comparative population surveys of random population samples from both areas in spring 1992 . The study included a self administered questionnaire, physical measurements and laboratory tests. The validity of self reported smoking prevalence was assessed by serum cotinine analyses.
\end{abstract}

Setting-The district of Pitkäranta in the Republic of Karelia, Russia and province of North Karelia, Finland.

Participants-The study population was a 25 to 64 year old population in both areas. A stratified random sample of 1000 people in Pitkäranta and 2000 people in North Karelia was drawn from the population registers. In Pitkäranta 380 men and 455 women, and in North Karelia 673 men and 803 women, participated in the survey.

Results-The self reported prevalence rates of daily smoking in Pitkäranta were $65 \%$ among men and $10 \%$ among women. In North Karelia the respective rates were $29 \%$ and $13 \%$. Women in Pitkäranta greatly underreported their smoking status, which was assessed by comparing the self reported data to the serum cotinine measurements. The smoking prevalence among women in Pitkäranta would rise from $10 \%$ to $21 \%$ if all participants with high cotinine values would be regarded as smokers. Compared with smokers in North Karelia, a higher percentage of smokers in Pitkäranta expressed their wish to quit and believed that they would succeed. However, on average they had fewer previous smoking cessation attempts than smokers in North Karelia. In addition, the health personnel in North Karelia were more active in advising smokers to quit.

National Public Health Institute, Department of Epidemiology and Health Promotion, Mannerheimintie 166, FIN-00300 Helsinki, Finland

Correspondence to: Dr T Laatikainen.

Accepted for publication 19 February 1999 among men in Pitkäranta obviously contributes much to the high premature death rate in the Republic of Karelia. There is considerable underreporting of smoking in Pitkäranta, especially among women, which is probably attributable to the cultural unacceptability of female smoking in Russia. The common wish to quit, few previous cessation attempts and much lower rates of ex smokers, together with less smoking cessation counselling from health personnel, need to be considered in tailoring antismoking interventions in the area.

(F Epidemiol Community Health 1999;53:528-534)

The health hazards of cigarette smoking became fully recognised in the late 1950 s and early $1960 \mathrm{~s}^{1}{ }^{1}$ Since then the role of smoking as a risk factor for cardiovascular diseases and several cancers has been well documented..$^{2-5}$ Changes in the prevalence of smoking have been assessed in most developed countries. During the 1970s the World Health Organisation (WHO) recommended active measures to decrease cigarette smoking. ${ }^{6}$ Since then cigarette smoking among men in most western countries has been decreasing, whereas the prevalence among women and men in eastern Europe and in developing countries has been increasing. $^{7-10}$

The prevalence of smoking among men in different areas of the USSR ranged from 35\% to $80 \%$ in the early 1980 s, while the prevalence among women was about $10 \% .{ }^{11}$ The smoking prevalence in the Russian Federation has continuously increased among both men and women. The prevalence of smoking for the adult male population increased from $45 \%$ in the early 1980 s to $60-70 \%$ in 1996 , the respective rise among women was from $10 \%$ to $20-30 \% .^{78} 11-13$

The total mortality in the Russian Federation is very high. The main characteristics are high cardiovascular disease and cancer mortality. ${ }^{14-16}$ It is estimated that about $18 \%$ of all deaths in the Russian Federation is attributable to tobacco use and as much as $45 \%$ among men ages 35 to $69 .^{317}$

The self reported smoking in population studies is considered to be rather reliable. ${ }^{18-20}$ The increasing social unacceptability of smoking could, however, have led to underreporting. ${ }^{21}{ }^{22}$ Several biochemical markers, for example cotinine, carbon monoxide and thiocyanate, have been used to validate self reported smoking. ${ }^{2123} 24$

For the planning of effective control proto the smoking cessation process. ${ }^{25}$ The desire to quit smoking positively correlates with the plan to quit smoking. ${ }^{26}$ Self efficacy - that is, the perceived capability to quit smoking - has been found to be a predictor of the intention to quit and especially to have an effect on the actors and maintainers in refraining from smoking. ${ }^{27-29}$ 
Table 1 Survey sample and participants

\begin{tabular}{|c|c|c|c|c|c|c|c|c|}
\hline & \multicolumn{4}{|c|}{ Republic of Karelia (Pitkäranta) } & \multicolumn{4}{|c|}{ North Karelia } \\
\hline & \multicolumn{2}{|l|}{ Men } & \multicolumn{2}{|l|}{ Women } & \multicolumn{2}{|l|}{ Men } & \multicolumn{2}{|l|}{ Women } \\
\hline & number & $\%$ & number & $\%$ & number & $\%$ & number & $\%$ \\
\hline Original sample & 500 & & 500 & & 1000 & & 1000 & \\
\hline Final sample & 495 & & 497 & & 988 & & 994 & \\
\hline \multicolumn{9}{|l|}{ Participants } \\
\hline \multicolumn{9}{|l|}{ Age } \\
\hline $25-34$ & 90 & 73 & 114 & 91 & 140 & 58 & 180 & 73 \\
\hline $35-44$ & 94 & 76 & 117 & 94 & 170 & 68 & 195 & 79 \\
\hline $45-54$ & 91 & 73 & 110 & 88 & 178 & 72 & 211 & 84 \\
\hline $55-64$ & 105 & 85 & 114 & 93 & 185 & 74 & 217 & 87 \\
\hline Total & 380 & 77 & 455 & 92 & 673 & 68 & 803 & 81 \\
\hline
\end{tabular}

It seems that successful smoking cessation is associated with previous attempts to quit, however there are some contradictory reports. ${ }^{26} 3032$ Positive social influence favour the smoking cessation process in all stages. ${ }^{28}{ }^{33}$ One dimension of the social influence is social support, which for example includes a health professional's advice to quit smoking. ${ }^{34} 35$

A population survey was carried out in spring 1992 in the Republic of Karelia in connection with a large national risk factor survey in Finland (The National FINRISK Study). One aim of this survey was to assess and validate self reported smoking prevalence in the Republic of Karelia, Russia and to compare the situation with the neighbouring Finnish area, North Karelia, where several antismoking activities have been carried out during recent decades. Another aim was to assess certain smoking cessation related process variables to support the planning of future preventive activities.

\section{Methods}

STUDY AREAS

The Republic of Karelia is part of the Russian Federation. Geographically, it is in the north western region of Russia and is bordered on the west by Finland (North Karelia). The area is very sparsely populated. In 1992 there were 798400 inhabitants in the Republic. ${ }^{36}$ According to official statistics the total mortality in 1991 in the age group 35-64 years was 1624 per 100000 among men and 552 per 100000 among women. ${ }^{37}$ One third of this mortality was attributable to cardiovascular disease.

The study was carried out in the area of Pitkäranta, as it was not feasible to include the whole Republic in the study. The area of Pitkäranta is one of the Republic's 15 rural districts. In addition there are two so called town districts. Statistical information indicated Pitkäranta to be a relatively typical area of the Republic. ${ }^{38}$ In 1990 there were 27500 inhabitants in the district of Pitkäranta. ${ }^{39}$

North Karelia is the most eastern province in Finland. There were 177670 inhabitants in 1992. The total mortality in 1991 in the age group 35-64 years was 866 among men and 285 among women. In North Karelia almost half of the mortality was attributable to cardiovascular disease. ${ }^{40}$

SUBJECTS

The survey population in both areas was the 25 to 64 year old population. An age stratified random sample was drawn from respective population registers. Each 10 year age and gender specific group contained 125 people in Pitkäranta and 250 in North Karelia. The total sample size was 1000 in Pitkäranta and 2000 in North Karelia. Participation rates were somewhat higher in Pitkäranta than in North Karelia and higher among women than among men in both areas. The survey participation rates were $77 \%$ of men and $92 \%$ of women in Pitkäranta and $68 \%$ of men and $81 \%$ of women in North Karelia (table 1).

SURVEY METHODS

The survey included a self administered questionnaire, physical measurements and laboratory tests. The survey methods followed the WHO MONICA protocol and were as identical as possible in both areas. ${ }^{41}{ }^{42}$ The survey was carried out in both areas by the same trained survey team. In North Karelia the survey was carried out from January to March and in Pitkäranta from March to April.

The questionnaire included questions about smoking history, prevalent smoking habits, use of health services and several smoking cessation related issues. Self reported daily smoking was assessed from a set of questions: "Have you ever smoked?", "Have you ever smoked regularly?" and "When did you last smoke?". Four different categories were used to categorise the smokers: daily smokers, occasional smokers, ex smokers and non-smokers. Passive smoking was assessed with the question: "How many hours daily do you stay in indoor places where somebody smokes?".

The validity of smoking was assessed by measuring the serum cotinine level from fresh serum samples. Blood samples were taken in the seated position in a smoke free place. Cotinine was measured by a Hewlett Packard gas chromatography (5890) mass spectrometer (5970, GC/MS) with a selected ion monitoring mode. The cut off point of $10 \mathrm{ng} / \mathrm{ml}$, which was the minimum detectable level of the method, was used in the analyses.

The determinants related to the smoking cessation process were assessed by the following questions: Desire to quit: "Would you like to stop smoking?", self efficacy: "If you would try to stop smoking, do you think you would be successful?", previous attempts to quit: "Have you ever tried seriously to stop smoking? If so, when was the last time?", social support/ pressure: "Has a physician advised you to quit during the last year?" and "Has a nurse or occupational health nurse advised you to quit during the last year?". Only those who had visited a physician, nurse or occupational health nurse during the preceding 12 months were included in the analyses.

Education was assessed with the question "How many years altogether have you gone to school or studied full time?" Educational groups were categorised by calculating education year tertiles by area, gender and 10 year age groups.

Statistical analyses were performed using SAS (Statistical Analysis System, version 6.07). Differences in prevalence between areas or socioeconomic factors were assessed using a 
Table 2 Self reported smoking by gender and area

\begin{tabular}{|c|c|c|c|c|c|c|c|c|}
\hline & \multicolumn{4}{|l|}{$M e n$} & \multicolumn{4}{|l|}{ Women } \\
\hline & \multicolumn{2}{|c|}{$\begin{array}{l}\text { Republic of } \\
\text { Karelia } \\
\text { (Pitkäranta) }\end{array}$} & \multicolumn{2}{|c|}{ North Karelia } & \multicolumn{2}{|c|}{$\begin{array}{l}\text { Republic of } \\
\text { Karelia } \\
\text { (Pitkäranta) }\end{array}$} & \multicolumn{2}{|c|}{ North Karelia } \\
\hline & number & $\%$ & number & $\%$ & number & $\%$ & number & $\%$ \\
\hline \multicolumn{9}{|l|}{ Current smoking } \\
\hline Daily smokers & 244 & 65 & 192 & 29 & 45 & 10 & 107 & 13 \\
\hline Occasional smokers & 9 & 2 & 34 & 5 & 22 & 5 & 36 & 4 \\
\hline Ex smokers & 55 & 15 & 173 & 26 & 15 & 3 & 100 & 12 \\
\hline Non-smokers & 70 & 19 & 268 & 40 & 369 & 82 & 558 & 70 \\
\hline Total & 378 & 100 & 667 & 100 & 451 & 100 & 801 & 100 \\
\hline
\end{tabular}

$\chi^{2}$ Test between areas. Men $\chi^{2}=128, \mathrm{p}<0.001$. Women $\chi^{2}=35, \mathrm{p}<0.001$.

$\chi^{2}$ test. Concerning smoking differences between age groups and education among men in Pitkäranta, statistical analyses were carried out, excluding occasional smokers because of their small cell size.

\section{Results}

SELF REPORTED SMOKING

In Pitkäranta $65 \%$ of men were daily smokers according to their self reports. In North Karelia the respective rate was $29 \%$. The self reported smoking prevalence among women was much lower; $10 \%$ in Pitkäranta and 13\% in North Karelia were daily smokers according to their self reports. The prevalence of ex smokers was significantly lower in Pitkäranta than in North Karelia among both men and women. In Pitkäranta $15 \%$ of men and $3 \%$ of women were quitters. The respective rates in North Karelia were $26 \%$ and $12 \%$. The proportion of ex smokers among the ever smokers was $18 \%$ among both men and women in Pitkäranta. In North Karelia the respective rates were $43 \%$ and $41 \%$ (table 2).

In Pitkäranta daily smoking was more common in younger age groups among both men and women. In the age group 25 to 34 years $76 \%$ of men were daily smokers. In North Karelia there were bigger differences between the age groups among women compared with men. However, daily smoking was more common among younger age groups. In both areas the proportion of ex smokers among men was higher in older age groups. Among women in North Karelia there were more ex smokers in younger age groups while in Pitkäranta no differences between age groups were evident (table 3).

In both areas the proportion of daily smokers among men was highest in the groups with fewer years of education. However, these differences were not statistically significant. Among women in Pitkäranta there were no significant differences in smoking status between the education groups. In North Karelia there were more daily smokers among women with fewer years of education.

In North Karelia married or cohabiting men smoked significantly less than unmarried men. Among women there was similar trend, but it was not statistically significant. In Pitkäranta there were no differences in smoking status by marital status.

\section{VALIDATION OF SMOKING}

Among men in Pitkäranta $17 \%(n=12)$ of self reported non-smokers had a serum cotinine level higher than $10 \mathrm{ng} / \mathrm{ml}$. In North Karelia the respective rate was $2 \% \quad(n=6)$. Among women in Pitkäranta $13 \% \quad(n=48)$ of self reported non-smokers had high serum cotinine levels. In North Karelia the respective rate was $2 \%(n=11)$ (table 4$)$.

In Pitkäranta only one man (0.4\%) and two women $(4.4 \%)$ who were self reported daily smokers had a serum cotinine value less than $10 \mathrm{ng} / \mathrm{ml}$. In North Karelia the respective

Table 3 Smoking and socioeconomic factors by gender and area

\begin{tabular}{|c|c|c|c|c|c|c|c|c|c|c|c|c|}
\hline & \multirow[b]{2}{*}{ number } & \multicolumn{5}{|c|}{ Republic of Karelia (Pitkäranta) } & \multirow[b]{2}{*}{ number } & \multicolumn{5}{|c|}{ North Karelia } \\
\hline & & $\begin{array}{l}\text { Daily } \\
\text { smoker } \\
(\%)\end{array}$ & $\begin{array}{l}\text { Occasional } \\
\text { smoker } \\
(\%)\end{array}$ & $\begin{array}{l}\text { Ex } \\
\text { smoker } \\
(\%)\end{array}$ & $\begin{array}{l}\text { Non- } \\
\text { smoker } \\
(\%)\end{array}$ & $\begin{array}{l}\chi^{2} \text { test } \\
(p \text { value })\end{array}$ & & $\begin{array}{l}\text { Daily } \\
\text { smoker } \\
(\%)\end{array}$ & $\begin{array}{l}\text { Occasional } \\
\text { smoker } \\
(\%)\end{array}$ & $\begin{array}{l}\text { Ex } \\
\text { smoker } \\
(\%)\end{array}$ & $\begin{array}{l}\text { Non- } \\
\text { smoker } \\
(\%)\end{array}$ & $\begin{array}{l}\chi^{2} \text { test } \\
(p \text { value })\end{array}$ \\
\hline \multicolumn{13}{|l|}{ Men } \\
\hline \multicolumn{13}{|l|}{ Age } \\
\hline $25-34$ & 90 & 76 & 4 & 4 & 16 & & 140 & 33 & 8 & 16 & 44 & \\
\hline $35-44$ & 93 & 61 & 1 & 17 & 20 & & 169 & 32 & 4 & 18 & 46 & \\
\hline $45-54$ & 91 & 67 & 3 & 5 & 24 & & 176 & 25 & 7 & 33 & 35 & \\
\hline $55-64$ & 104 & 56 & 1 & 29 & 14 & $<0.001 \ddagger$ & 182 & 26 & 2 & 34 & 38 & $<0.001$ \\
\hline \multicolumn{13}{|l|}{ Marital status ${ }^{\star}$} \\
\hline Married & 340 & 63 & 3 & 15 & 19 & & 529 & 26 & 4 & 28 & 42 & \\
\hline Unmarried & 38 & 76 & 0 & 11 & 13 & $=0.386$ & 138 & 39 & 9 & 17 & 35 & $<0.001$ \\
\hline \multicolumn{13}{|l|}{ Education $\dagger$} \\
\hline Lower & 121 & 70 & 1 & 15 & 14 & & 219 & 32 & 7 & 24 & 37 & \\
\hline Medium & 130 & 68 & 4 & 10 & 18 & & 221 & 31 & 3 & 29 & 37 & \\
\hline Higher & 125 & 56 & 2 & 19 & 22 & $=0.085 \ddagger$ & 225 & 24 & 6 & 25 & 46 & $=0.067$ \\
\hline \multicolumn{13}{|l|}{ Women } \\
\hline \multicolumn{13}{|l|}{ Age } \\
\hline $25-34$ & 114 & 19 & 6 & 6 & 68 & & 179 & 20 & 7 & 20 & 53 & \\
\hline $35-44$ & 115 & 12 & 8 & 2 & 78 & & 195 & 17 & 8 & 18 & 57 & \\
\hline $45-54$ & 109 & 6 & 6 & 2 & 87 & & 211 & 12 & 3 & 7 & 78 & \\
\hline $55-64$ & 113 & 3 & 0 & 4 & 94 & $<0.001 \ddagger$ & 216 & 6 & 1 & 6 & 87 & $<0.001$ \\
\hline \multicolumn{13}{|l|}{ Marital status $\star$} \\
\hline Married & 346 & 11 & 4 & 4 & 81 & & 625 & 12 & 4 & 14 & 70 & \\
\hline Unmarried & 105 & 8 & 7 & 2 & 84 & $=0.465$ & 175 & 17 & 6 & 7 & 70 & $=0.052$ \\
\hline \multicolumn{13}{|l|}{ Education $\dagger$} \\
\hline Lower & 149 & 13 & 5 & 3 & 79 & & 245 & 18 & 3 & 10 & 69 & \\
\hline Medium & 137 & 9 & 4 & 2 & 85 & & 295 & 15 & 6 & 16 & 63 & \\
\hline Higher & 163 & 8 & 6 & 4 & 82 & $=0.655$ & 260 & 7 & 5 & 11 & 77 & $<0.001$ \\
\hline
\end{tabular}

${ }^{\star}$ Married includes married and cohabiting, unmarried includes unmarried, divorced and widowed. $†$ Tertiles from years of education by area, gender and 10 year age groups. $¥$ Statistical analysis carried out between daily smokers, ex smokers and non-smokers, because of the small cell size of occasional smokers. 
Table 4 Serum cotinine concentrations $(\mathrm{ng} / \mathrm{ml})$ and self reported smoking by gender and area

\begin{tabular}{|c|c|c|c|c|c|c|c|c|c|c|}
\hline \multirow[b]{2}{*}{$\begin{array}{l}\text { Cotinine } \\
\text { concentration ( } \mathrm{ng} / \mathrm{ml})\end{array}$} & \multicolumn{5}{|c|}{ Republic of Karelia (Pitkäranta) } & \multicolumn{5}{|l|}{ North Karelia } \\
\hline & $\begin{array}{l}\text { Daily smoker } \\
(\%)\end{array}$ & $\begin{array}{l}\text { Occasional } \\
\text { smoker (\%) }\end{array}$ & $\begin{array}{l}\text { Ex smoker } \\
(\%)\end{array}$ & $\begin{array}{l}\text { Non-smoker } \\
(\%)\end{array}$ & Total (\%) & $\begin{array}{l}\text { Daily smoker } \\
(\%)\end{array}$ & $\begin{array}{l}\text { Occasional } \\
\text { smoker }(\%)\end{array}$ & $\begin{array}{l}\text { Ex smoker } \\
(\%)\end{array}$ & $\begin{array}{l}\text { Non-smoker } \\
(\%)\end{array}$ & Total (\%) \\
\hline \multicolumn{11}{|l|}{ Men } \\
\hline 0 & 0.4 & 0.0 & 94.6 & 82.9 & 29.6 & 3.2 & 64.7 & 91.1 & 97.7 & 67.1 \\
\hline $10-19$ & 0 & 0 & 0 & 4.3 & 0.8 & 1.6 & 0 & 1.8 & 0.8 & 1.2 \\
\hline $20-49$ & 2.1 & 33.3 & 3.6 & 5.7 & 3.7 & 6.9 & 11.8 & 4.7 & 0.8 & 4.1 \\
\hline $50-$ & 97.5 & 66.7 & 1.8 & 7.1 & 65.9 & 88.3 & 23.5 & 2.4 & 0.8 & 27.6 \\
\hline Total (\%) & 64.3 & 2.4 & 14.7 & 18.7 & 100.0 & 28.8 & 5.2 & 25.9 & 40.1 & 100.0 \\
\hline Number & 241 & 9 & 55 & 70 & 375 & 188 & 34 & 169 & 262 & 653 \\
\hline \multicolumn{11}{|l|}{ Women } \\
\hline 0 & 4.4 & 27.3 & 80.0 & 87.0 & 75.6 & 3.8 & 42.9 & 90.8 & 98.0 & 81.9 \\
\hline $10-19$ & 0 & 9.1 & 0 & 1.9 & 2.0 & 2.9 & 2.9 & 4.1 & 0.7 & 1.5 \\
\hline $20-49$ & 2.2 & 9.1 & 0 & 3.5 & 3.6 & 6.7 & 20.0 & 2.0 & 0.7 & 2.6 \\
\hline $50-$ & 93.3 & 54.6 & 20.0 & 7.6 & 18.9 & 86.7 & 34.3 & 3.1 & 0.6 & 14.0 \\
\hline Total (\%) & 10.0 & 4.9 & 3.3 & 81.8 & 100.0 & 13.5 & 4.5 & 12.6 & 69.4 & 100.0 \\
\hline Number & 45 & 22 & 15 & 368 & 450 & 105 & 35 & 98 & 540 & 778 \\
\hline
\end{tabular}

figures were six for men $(3.2 \%)$ and four for women $(3.8 \%)$ (table 4$)$.

If all those who reported to be non-smokers, or to have quit more than one month prior, and who still had serum cotinine levels above 10 $\mathrm{ng} / \mathrm{ml}$ were categorised as daily smokers, the smoking prevalence would rise in Pitkäranta from $65 \%$ to $68 \%$ among men and from $10 \%$ to $21 \%$ among women and in North Karelia from $29 \%$ to $32 \%$ among men and from $13 \%$ to $16 \%$ among women. Underreporters did not differ from accurate reporters in age, education or marital status.

SMOKING CESSATION PROCESS VARIABLES

In Pitkäranta a bigger proportion of daily smoking men $(76 \%)$ and women $(71 \%)$ expressed a desire to quit smoking than in North Karelia (61\% v 64\%). Among women this difference was not statistically significant. In Pitkäranta $32 \%$ of men and $27 \%$ of women believed that they would succeed in smoking cessation. The respective rates in North Karelia were $22 \%$ and $32 \%$. In North Karelia there were significantly more male smokers who could not give an opinion on their success in quitting (table 5).

In Pitkäranta $62 \%$ of male smokers and $56 \%$ of female smokers had never attempted to quit. The respective rates in North Karelia were $35 \%$ and $34 \%$. There was no significant difference between the areas in receiving cessation advice from a physician; about $30 \%$ of smokers had received such advice. The counselling activity among nurses was significantly higher in North Karelia than in Pitkäranta. About $40 \%$ of smokers in North Karelia had received advice to quit from nurses or occupational

Table 5 Smoking cessation process related variables among daily smokers by area and gender

\begin{tabular}{|c|c|c|c|c|c|c|c|c|}
\hline & \multicolumn{4}{|l|}{ Men } & \multicolumn{4}{|l|}{ Women } \\
\hline & \multicolumn{2}{|c|}{$\begin{array}{l}\text { Republic of Karelia } \\
\text { (Pitkäranta) }\end{array}$} & \multicolumn{2}{|c|}{ North Karelia } & \multicolumn{2}{|c|}{$\begin{array}{l}\text { Republic of Karelia } \\
\text { (Pitkäranta) }\end{array}$} & \multicolumn{2}{|c|}{ North Karelia } \\
\hline & number & $\%$ & number & $\%$ & number & $\%$ & number & $\%$ \\
\hline \multicolumn{9}{|l|}{ Desire to quit } \\
\hline No & 25 & 10 & 19 & 10 & 6 & 13 & 8 & 7 \\
\hline Yes & 185 & 76 & 118 & 61 & 32 & 71 & 68 & 64 \\
\hline Do not know & 34 & 14 & 55 & 29 & 7 & 16 & 31 & 29 \\
\hline \multicolumn{9}{|l|}{ Belief in successfully quitting } \\
\hline No & 73 & 30 & 40 & 21 & 16 & 36 & 26 & 24 \\
\hline Yes & 78 & 32 & 43 & 22 & 12 & 27 & 35 & 32 \\
\hline Do not know & 93 & 38 & 109 & 57 & 17 & 38 & 46 & 43 \\
\hline \multicolumn{9}{|l|}{ Previously attempted to quit } \\
\hline Never & 150 & 62 & 67 & 35 & 25 & 56 & 36 & 34 \\
\hline More than year ago & 62 & 26 & 95 & 50 & 10 & 22 & 50 & 47 \\
\hline 1 month -12 months ago & 26 & 11 & 18 & 9 & 5 & 11 & 16 & 15 \\
\hline Less than 1 month ago & 3 & 1 & 11 & 6 & 5 & 11 & 5 & 5 \\
\hline \multicolumn{9}{|l|}{ Physicians advice to quit* ${ }^{\star}$} \\
\hline No & 136 & 67 & 102 & 68 & 32 & 80 & 65 & 68 \\
\hline Yes & 67 & 33 & 48 & 32 & 8 & 20 & 30 & 32 \\
\hline \multicolumn{9}{|l|}{ Nurses advice to quit $\dagger$} \\
\hline No & 123 & 77 & 65 & 58 & 30 & 88 & 45 & 65 \\
\hline Yes & 65 & 23 & 47 & 42 & 4 & 12 & 24 & 35 \\
\hline \multicolumn{9}{|c|}{ Health professionals advice to quit $\ddagger$} \\
\hline No & 133 & 64 & 88 & 56 & 31 & 78 & 60 & 61 \\
\hline Yes & 74 & 36 & 70 & 44 & 9 & 23 & 39 & 39 \\
\hline
\end{tabular}

^Physicians advice during preceding 12 months among those who visited a physician at least once. $†$ Nurses or occupational health nurses advice during preceding 12 months among those who visited a nurse or occupational health nurse at least once. $\ddagger$ Physicians, nurses or occupational health nurses advice during preceding 12 months among those who visited the mentioned health personnel at least once.

$\chi^{2}$ test between areas

Desire to quit

Belief in successfully quitting Previously attempted to quit

Physicians advice to quit

$\begin{array}{ll}\text { Nurses advice to quit } & \chi^{2}=11.5 \\ \text { Health professionals advice to quit } & \chi^{2}=2.7\end{array}$

Men

Women

$\mathrm{p}<0.001 \quad \chi^{2}=2.0 \quad \mathrm{p}=0.362$

$\mathrm{p}<0.001 \quad \chi^{2}=10.9 \quad \mathrm{p}=0.012$

$\mathrm{p}<0.001 \quad \chi^{2}=6.1 \quad \mathrm{p}=0.014$ 
health nurses, while the respective rate in Pitkäranta was less than $20 \%$. When all the health personnel were considered together there was no significant difference between areas or sexes in the amount of cessation advice received (table 5).

\section{Discussion}

Previous information on health behaviour and related variables in the Republic of Karelia, and even in Russia as a whole, has been relatively scarce. Thus it was most interesting to assess smoking prevalence and smoking change process variables in a representative and well standardised population survey of a random population sample in the district of Pitkäranta in the Republic of Karelia, and to compare the data with the neighbouring Finnish province of North Karelia, where many antismoking activities have been carried out during the past 20 years. ${ }^{43}$ While these areas are geographically very close they are economically, politically and culturally very different because of the isolation of the Republic of Karelia during the Soviet era.

The risk factor surveys in both areas were carried out by the same survey team, using the same standardised methods as identically as possible. The only dissimilarities between the surveys were small differences in the time periods of performing the surveys; there was a little longer time between the laboratory tests and analyses concerning the Pitkäranta samples and the procedure of completing the survey questionnaire.

In North Karelia the questionnaire was mailed to the participants and mainly completed at home while the Pitkäranta participants completed the questionnaire at the survey place. The short time gap between the completion of the questionnaire and the laboratory tests in North Karelia might have some impact on the validation results for self reported smoking by serum cotinine levels. Otherwise these differences are unlikely to have a major impact on the results.

The smoking prevalence in Pitkäranta was extremely high among men and rather low among women, as indicated by other studies made elsewhere in the Russian Federation. ${ }^{8111244}$ The finding that smoking is most prevalent in younger age groups among both men and women might reflect the continuous increase in smoking in the Republic of Karelia as described in other parts of the Russian Federation. ${ }^{12}$

Three phases in smoking development have been described in industrialised countries. In the first phase smoking is common in men, but rather uncommon in women. In the second phase men start to stop smoking but more women start to smoke. In the third phase women also start to quit, and smoking becomes equally common among both sexes. ${ }^{45}$ At present, the Pitkäranta area seems to be in the first phase with a large gap in smoking prevalence between men and women and a rather small proportion of ex smokers among both genders. However, it seems that the population is approaching the second phase
KEY POINTS

- Smoking is very prevalent among men in the Republic of Karelia. This contributes much to the very high premature mortality rates in the area.

- In contrast, smoking prevalence is quite low among women in the Republic of Karelia. Compared with men, however, it seems that women are more likely to underreport their smoking status. This relates to the cultural unacceptability of smoking among women in Russia.

- The very high smoking prevalence among men and the predictable increase in smoking among women pose a great challenge to public health policy.

- Furthermore, smokers in the Republic of Karelia are generally in an early phase of the smoking cessation process. This should be carefully taken into account when tailoring feasible antismoking activities.

with a predictable increase in smoking prevalence among women and a little higher proportion of ex smokers among men. A diffusion of the cessation innovation, starting usually in highly educated people, could also be seen as there was a slightly higher proportion of ex smokers among highly educated men compared with other educational groups. ${ }^{46}$

In 1992 the North Karelian population was in phase two in its smoking development. However, the increase in smoking prevalence among women was rather small in past decades and recently levelled off, possibly because of the antismoking activities. ${ }^{47}$ It is probable that the smoking prevalence among women will never reach that of men. According to this experience in North Karelia you might wonder whether the Republic of Karelia has to go all the way through the described smoking development phases, or could we achieve a more positive development through effective antismoking activities? Sufficient investment of resources to prevent the onset of smoking would be the most efficient way to avoid a negative development in smoking prevalence in the Republic of Karelia.

Differences in smoking between the educational groups have been described in previous studies in Finland both among men and women. Educational differences in smoking prevalent among men since the 1970s were slightly increasing until the 1990s. Among women the difference became significant in the mid-1980s and had been increasing more rapidly than differences among men. ${ }^{48}$ In 1992 the differences in smoking between educational groups seemed to be smaller among North Karelian men compared with other men in Finland, but the differences among women were rather similar. It is possible that practical, community-based intervention has favoured men with less education more than other segments of the Finnish population..$^{43}$ In accordance with a study of Russian smoking 
patterns by McKee et al education was not associated with smoking in the Republic of Karelia. ${ }^{13}$

The underreporting of smoking is more likely to occur when there is pressure against smoking, such as in smoking cessation trials, clinical settings and among people with smoking related diseases, than in cross sectional population surveys. ${ }^{21}{ }^{50}$ In Pitkäranta $17 \%$ of self reported non-smoking men and $13 \%$ of non-smoking women had cotinine in serum. In North Karelia the respective rates were 2\% among both men and women. The underreporting of smoking seems to be more common in the Republic of Karelia than in North Karelia. The rates in North Karelia are comparable to rates shown in other population surveys. ${ }^{18-20}$ In the Republic of Karelia the prevalence of female smoking is likely to be twice as high as indicated by self reported data. Nikitin et al have described a similar discrepancy between self reported smoking and thiocyanate validated smoking rates among women in Novosibirsk, Russia. ${ }^{44}$

Some factors might explain the discrepancy between self reported smoking and serum cotinine levels. In North Karelia there was a short time difference between the participants' completion of the questionnaire and their laboratory tests, but this can only affect the North Karelian data. In the Republic of Karelia the tests were made immediately after the participants completed the questionnaire. Use of smokeless tobacco or nicotine replacement therapy were not included in the questionnaire, but in the Republic of Karelia snuffing is hardly known and nicotine replacement therapy was not available. The effect of passive smoking should also be considered. However, the effect of passive smoking on cotinine level is small and the cotinine values usually rises only to levels $0.5 \mathrm{ng} / \mathrm{ml}$ to $10 \mathrm{ng} / \mathrm{ml} .{ }^{51}{ }^{52}$ Passive smoking was assessed and did not explain the high cotinine values among non-smokers. In the Republic of Karelia very few surveys have been carried out, and the population is not very familiar with completing questionnaires. This might have some effect on the self reported smoking data. However, none of the aforementioned factors are likely to explain the large discrepancy between the self reported smoking rates and serum cotinine levels among women in the Republic of Karelia. Thus the most probable explanation is the cultural unacceptability of smoking among women in Russia.

Concerning the desire and self efficacy to quit, measuring the intention to quit could be a better method than the desire to quit when assessing the cessation process. ${ }^{29} 53$ When measuring self efficacy items it would be more accurate to assess the confidence in controlling the behaviour in well described, specific situations instead of assessing perceived confidence in general..$^{54}$ Despite these weaknesses, these comparable studies give us interesting information on the status of smoking cessation processes in both North Karelia and the Republic of Karelia.
Compared with North Karelia, a significantly higher proportion of male smokers in the Republic of Karelia expressed a desire to quit and believed they would succeed. However, over $60 \%$ of male smokers in that area had never tried to quit smoking. The respective rate in North Karelia was 35\%. Bandura indicates that self efficacy expectations increase through successive mastery of behaviour while repeated failures lower them. ${ }^{55}$ This could explain why North Karelian smokers who have more previous cessation attempts have less confidence that they will succeed. Clark et al found a significant association with previous smoking cessation attempts and intention to quit, new attempts to quit and also with successful quitting with a three month follow up period. ${ }^{26}$ According to this experience North Karelian smokers would benefit in the cessation process from their previous attempts to quit.

Only nurses' activity in smoking cessation counselling was significantly different between North Karelia and the Republic of Karelia. In the context of the North Karelia project, several antismoking interventions including effective training of health professionals, especially public health nurses, have been carried out during the past 20 years. ${ }^{43}{ }^{56}$ It is remarkable that we did not find any difference in physicians' counselling activity between North Karelia and the Republic of Karelia, where hardly any antismoking activities have been carried out. Korhonen et al found that the proportion of male smokers advised by physician was significantly higher in North Karelia than elsewhere in Finland. ${ }^{56}$

High smoking prevalence among men together with widespread passive smoking in the Republic of Karelia could explain much of the area's higher mortality rate. The predicted increase in smoking poses a great challenge to the health authorities. The high proportion of male smokers with a desire to quit and no previous cessation attempts creates a need for tailored antismoking interventions. Intensified training of nurses on smoking cessation counselling and carefully addressed advice to quit by health professionals, together with feasible media campaigns, could be a cost effective way in creating the first antismoking activities in the Republic of Karelia. ${ }^{57}$

The authors gratefully acknowledge Dr Mihail Uhanov, Dr Svetlana Pokusajeva and Dr Nina Moisejeva for their practical assistance in carrying out the survey in spring 1992.

Conflicts of interest: none.

1 Smoking and health. Report of the advisory committee to Surgeon General of the Public Health Service. Washington DC: US Public Health Service, 1964. PHS Publication no 1103

2 Doll R, Peto R, Wheatley K, et al. Mortality in relation to smoking: 40 years observation on male British doctors. BMF 1994;309:901-11.

3 Peto R, Lopez AD, Boreham J, et al. Mortality from tobacco in developed countries: indirect estimation from national vital statistics. Lancet 1992;339:1268-78.

4 Parish S, Collins R, Peto R, et al. For the International Studies of Infarct Survival (ISIS) Collaborators. Cigarette Studies of Infarct Survival (ISIS) Collaborators. Cigarette moking, tar yields, and non-fatal myocardial infarction: 14000 cases and 32000

5 Dreyer L, Winther JF, Pukkala E, et al. Tobacco smoking. Acta Pathologica, Mikrobiologica et Immunologica ScandiActa Pathologica, Mikrobiologica
navica 1997;105 (suppl 76):9-47. 
6 WHO Regional Office for Europe. Handbook of resolutions and decisions of the Regional Committee for Europe. Volume I. Twelfth edition covering the period 1951-1987. Copenhagen: WHO Europe, 1989.

7 Dobson AJ, Kuulasmaa K, Moltchanov V, et al. For the WHO MONICA Project. Changes in cigarette smoking among adults in 35 populations in the mid-1980s. Tobacco Control 1998;7:14-21

8 WHO Programme on Substance abuse: (prepared by Collishaw NE, Lopez AD). The tobacco epidemic: a global public health emergency. Tobacco Alert 1996; Apr.

9 Pierce JP. International comparison of trends in cigarette smoking prevalence. Am f Public Health 1989;79:152-7.

10 The WHO MONICA Project: (prepared by Pajak A Kuulasmaa K, Tuomilehto J, et al). Geographical variation in the major risk factors of coronary heart disease in men and women aged 35-64 years. World Health Stat $Q$ 1988;41:115-40.

11 Zaridze DG, Dvoirin VV, Kobljakov VA, et al. Smoking patterns in the USSR. IARC Scientific Publications 1986;74: 75-86.

12 Harkin AM, Anderson P, Goos C. Smoking, drinking and drug taking in the European Region. Alcohol, Drugs and drug taking in the European Region. Alcohol, Drugs and Tobacco Programme. Copenhagen: Worl
tion Regional Office for Europe, 1997.

13 McKee M, Bobak M, Rose R, et al. Patterns of smoking in Russia. Tobacco Control 1998;7:22-6.

14 Leon DA, Chenet L, Shkolnikov VM, et al. Huge variation in Russian mortality rates 1984-1994: artefact, alcohol, or what? Lancet 1997;350:383-8.

15 Virganskaya IM, Dmitriev VI. Some problems of medicodemographic development in the former USSR. World Health Stat $O$ 1992;45:4-14.

16 Sans S, Kesteloot H, Kromhout D. On behalf of the Task Force of the European Society of Cardiology on Cardiovascular Mortality and Morbidity Statistics in Europe. The burden of cardiovascular disease mortality in Europe. Eur Heart f 1997; 18:1231-48.

17 World Health Organization. Tobacco or Health Programme. A Global Status Report. Country Profiles by Region, 1997. (cited 1998 Sep 9). Available from: URL: http:// www.cdc.gov/nccdphp/osh/who/whoeupro.htm

18 Patrick DL, Cheadle A, Thompson DC, et al. The validity of self-reported smoking: A review and meta-analysis. $A m \mathcal{F}$ self-reported smoking: A review
Public Health 1994;84:1086-93.

19 Slattery ML, Hunt SC, French TK, et al. Validity of cigarette smoking habits in three epidemiologic studies in Utah. Prev Med 1989;18:11-19.

20 Woodward $\mathrm{M}$, Tunstall-Pedoe $\mathrm{H}$. An iterative technique for identifying smoking deceivers with application to the Scottish Heart Health Study. Prev Med 1992;21:88-97.

21 Jarvis MJ, Tunstall-Pedoe H, Feyerabend C, et al. Comparison of tests used to distinguish smokers from nonsmokers. Am 7 Public Health 1987;77:1435-8.

22 Sillett RW, Wilson MB, Malcolm RE, et al. Deception among smokers. BMF 1978;2:1185-6.

23 Suadicani P, Hein HO, Gyntelberg F. Serum validated tobacco use and social inequalities in risk of ischemic heart disease. Int $\mathcal{F}$ Epidemiol 1994;23:293-300.

24 Pierce JP, Dwyer T, DiGiusto E, et al, and Quit for Life Steering Committee. Cotinine validation of self-reported smoking in commercially run community surveys. 7 Chron Dis 1987;40:689-95.

25 Green LW, Kreuter MW. Health promotion planning: an educational and environmental approach. Mountain View (CA) Mayfield, 1991.

26 Clark MA, Kviz FJ, Crittenden KS, et al. Psychosocial factors and smoking cessation behaviors among smokers who
have and have not ever tried to quit. Health Educ Res 1998; have and have $145-53$.

27 Stretcher VJ, De Vellis BM, Becker MH, et al. The role of self-efficacy in achieving health behavior change. Health Educ Q 1986;13:73-91.

28 De Vries H, Backbier E. Self-efficacy as an important determinant of quitting among pregnant women who smoke: the Ø-Pattern. Prev Med 1994;23:167-74.

29 Ajzen I, Madden JT. Prediction of goal-directed behaviour: attitudes, intentions, and perceived behavioral control. $\mathscr{f}$ Exp Soc Psychol 1986;22:453-74.

30 Senore C, Battista RN, Shapiro SH, et al. Predictors of smoking cessation following physicians' counselling. Prev Med 1998;27:412-21

31 Hymowitz N, Sexton M, Ockene J, et al. Baseline factors associated with smoking cessation and relapse. Prev Med 1991;20:590-601.
32 Cohen S, Lichtenstein E, Prochaska JO, et al. Debunking myths about self-quitting: evidence from 10 prospective
studies of persons who attempt to quit smoking by studies of persons who attempt to quit
themselves. Am Psychol 1989;44:1355-65.

33 Zimmerman RS, Connor C. Health promotion in context: The effects of significant others on health behavior change. Health Educ Q 1989;16:57-75.

34 Silagy C, Ketteridge S. Physician advice for smoking cessation (Cochrane Review). In: The Cochrane Library, Issue 3, 1998. Oxford: Update Software.

35 Kvitz FJ, Clark MA, Prohaska TR, et al. Attitudes and practices for smoking cessation counselling by provider type and patient age. Prev Med 1995;24:201-12.

36 State Committee of the Republic of Karelia on Statistics. Republic of Karelia in Figures '97. Petrozavodsk: Goskomstat of the Republic of Karelia, 1997.

37 Ministry of Public Health, Republic of Karelia. Mortality Statistics (database). Petrozavodsk: Ministry of Public Health, 1991.

38 Statistical Office of Karelia. Republic of Karelia in Figures 1986-1990. (In Russian) Petrozavodsk: Goskomstat of the Republic of Karelia, 1991.

39 Varis E. Karjalan tasavalta tänään (The Republic of Karelia Today). Joensuun Yliopiston ja Pohjois-Karjalan lääninhallituksen julkaisuja (Publications of the University of Joensuu and the Provincial government of North Karelia, Finland). Joensuu: Pohjois-Karjalan lääninhallitus, 1993.

40 Tilastokeskus (Statistics Finland). Kuolleet ja kuolleisuus kuolinsyittäin: Läänit 1991 (Mortality and causes of death: Counties 1991). Helsinki: Statistics Finland, 1992.

41 WHO MONICA Project: (prepared by H Tunstall-Pedoe). The World Health Organization MONICA Project (monitoring trends and determinants in cardiovascular disease): major international collaboration. F Clin Epidemiol 1988; 41:105-14.

42 Puska P, Matilainen T, Jousilahti P, et al. Cardiovascular risk factors in the Republic of Karelia, Russia, and in North Karelia, Finland. Int $\mathcal{F}$ Epidemiol 1993;22:1048-55.

43 Puska P, Tuomilehto J, Nissinen A, et al. The North Karelia Project: 20 year results and experiences. Helsinki: Helsinki University Printing House, 1995.

44 Nikitin YP, Shalaurova IY, Serova NV. The validation of serum thiocyanate smoking data in a population survey. Rev Epidemiol Sante Publique 1990;38:469-72.

45 Piha T. Tobacco control activities of the World Health Organization in Europe. In: Richmond R, editor. Interventions for smokers: an international perspective. New York: Wiliams and Wilkins, 1994:323-47.

46 Rogers EM. Diffusion of innovations. 4th ed. New York: Collier Macmillian Publishers, 1995.

47 Puska P, Korhonen HJ, Uutela A, et al. Anti-smoking policy in Finland. In: Puska P, Elovainio L, Vertio H, eds. Smokefree Europe: a forum for networks. Jyväskylä: Finnish Centre for Health Promotion, 1997:26-42.

48 Helakorpi S, Uutela A, Prättälä R, et al. Health behavior among Finnish adult population, spring 1997. Helsinki: National Public Health Institute, 1997.

49 Puska P, Tuomilehto J, Salonen J, et al. Community control of cardiovascular diseases: The North Karelia Project. Copenhagen: WHO, 1981:153-6.

50 Murray RP, Connet JE, Lauger GG, et al, for the Lung Helath Study Research Group. Error in smoking measures: effects of intervention on relations of cotinine and carbon monoxide to self-reported smoking. Am 7 Public Health 1993;83:1251-7.

51 Emmons KM, Abrams DB, Marshall R, et al. An evaluation of the relationship between self-report and biochemical measures of environmental tobacco smoke exposure. Prev Med 1994;23: 35-9.

52 Kemmeren JM, Van Poppel G, Verhoef P, et al. Plasma cotinine: stability in smokers and validation of self-reported smoke exposure in nonsmokers. Environ Res 1994;66: 235-43.

53 DiClemente C, Prochaska JO, Fairhurst SK, et al. The process of smoking cessation: an analysis of precontemplation, contemplation and preparation stages of change. $\mathcal{F}$ Consult Clin Psychol 1991;59:295-304.

54 Maibach E, Murphy D. Self-efficacy in health promotion research and practice: conceptualization and measurement. research and practice: conceptualiz
Health Educ Res 1995;10:37-50.

55 Bandura A. Social foundation of thought and action. A social cognitive theory. New York: Prentice-Hall, 1986.

56 Korhonen T, Uutela A, Korhonen HJ, et al. Smoking cessation advice from health professionals: process evaluation of community-based program. Patient Education and Counselling 1999;36:13-21.

57 Cummings SR, Rubin SM, Oster G. The cost-effectiveness of counselling smokers to quit. $¥ A M A 1989 ; 261: 75-9$. 